\title{
HYPERSTABILITY OF A MIXED TYPE CUBIC-QUARTIC FUNCTIONAL EQUATION IN ULTRAMETRIC SPACES
}

\author{
Youssef Aribou, Hajira Dimou And SAmir KabBaj
}

Abstract. In this paper, we present the hyperstability results of a mixed type cubic- quartic functional equations in ultrametric Banach spaces.

Mathematics subject classification (2010): 39B82, 39B52, 47H10.

Keywords and phrases: Stability, hyperstability, ultrametric space, cubic functional equation.

\section{REFERENCES}

[1] M. Abramowitz and I. A. Stegun (EdS), Handbook of Mathematical Functions with Formulas, Graphs, and Mathematical Tables, National Bureau of Standards, Applied Mathematics Series 55, 9th printing, Washington, 1970.

[2] W. BURNSIDE, A rapidly convergent series for $\log N$ !, Messenger Math., 46, 1 (1917), 157-159.

[3] A. BAhYRYCZ, J. BRZDȨK AND M. PISZCZEK, On approximately $p$-Wright afine functions in ultrametric spaces, J. Funct. Spaces Appl. 2013, Art. ID 723545.

[4] A. BAhYRYCZ AND M. PISZCZEK, Hyperstability of the Jensen functional equation, Acta Math. Hungar., 142 (2014), 353-365.

[5] A. BAhyrycZ And J. OlKo, Stability of the equation of $(p, q)$-Wright functions, Acta Math. Hung., 146 (2015), 71-85.

[6] A. Bahyrycz And J. Olko, On stability of the general linear equation, Aequationes Math., 89 (2015), 1461-1474.

[7] A. Bodaghi, D. Kang And J. M. Rassias, The mixed cubic-quartic functional equation, An. Stiint. Univ. Al. I. Cuza Iasi. Mat. (N.S.), 63 (2017) no. 1, 215-227.

[8] D. G. Bourgin, Approximately isometric and multiplicative transformations on continuous function rings, Duke Math. J. 16 (1949), 385-397.

[9] J. BRZDȨK, J. ChUdZIAK AND Zs. PÁLES, A fixed point approach to stability of functional equations, Nonlinear Anal., 74 (2011), 6728-6732.

[10] J. BRZDȨK AND K. CIEPLIŃSKI, A fixed point approach to the stability of functional equations in non-Archimedean metric spaces, Nonlinear Analysis 74 (2011), 6861-6867.

[11] J. BRZDȨK, Hyperstability of the Cauchy equation on restricted domains, Acta Math. Hungar., 141 (2013), 58-67.

[12] J. BRZDȨK, Remarks on hyperstability of the Cauchy functional equation, Aequationes Math., 86 (2013), 255-267.

[13] J. BRZDȨK, A hyperstability result for the Cauchy equation, Bull. Aust. Math. Soc., 89 (2014), 33-40.

[14] J. BRZDȨK AND K. Cieplińs KI, Hyperstability and superstability, Abs. Appl. Anal., 2013, Article ID 401756, 13 pp. (2013).

[15] M. Eshaghi Gordji, S. Zolfaghari, J. M. Rassias And M. B. SavadKouhi, Solution and stability of a mixed type cubic and quartic functional equation in quasi-Banach spaces, Abstr. Appl. Anal., 2009, article ID 417473, 14 pp.

[16] P. GĂVRUŢA, A generalization of the Hyers-Ulam-Rassias stability of approximately additive mappings, J. Math. Anal. Appl. 184 (1994), 431-436.

[17] E. Gselmann, Hyperstability of a functional equation, Acta Math. Hungar., 124 (2009), 179-188.

[18] D. H. Hyers, On the stability of the linear functional equation, Proc. Natl. Acad. Sci. U.S.A., 27 (1941), 222-224. 
[19] B. Jessen, J. KARPF AND A. Thorup, Some functional equations in groups and rings, Math. Scand., 22 (1968), 257-265.

[20] A. Khrennikov, Non-Archimedean Analysis: Quantum Paradoxes, Dynamical Systems and Biological Models, Kluwer Academic Publishers, Dordrecht, 1997.

[21] Gy. MAKSA AND Zs. PÁLES, Hyperstability of a class of linear functional equations, Acta Math., 17 (2) (2001), 107-112.

[22] M. PISZCZEK, Remark on hyperstability of the general linear equation, Aequationes math., 88 (1) (2014), 163-168.

[23] TH. M. Rassias, On the stability of the linear mapping in Banach spaces, Proc. Amer. Math. Soc., 72 (1978), 297-300.

[24] M. Sirouni AND S. KABBAJ, A fixed point approach to the hyperstability of Drygas functional equation in metric spaces, J. Math. Comput. Sci., 4 (4) (2014), 705-715.

[25] S. M. Ulam, Problems in Modern Mathematics, Science Editions, John-Wiley \& Sons Inc. (New York, 1964).

[26] D. ZHANG, On Hyers-Ulam stability of generalized linear functional equation and its induced HyersUlam programming problem, Aequationes Math., 90 (2016), 559-568.

[27] D. ZHANG, On hyperstability of generalised linear functional equations in several variables, Bull. Aust. Math. Soc., 92 (2015), 259-267. 